\title{
CCL20 wt Allele
}

National Cancer Institute

\section{Source}

National Cancer Institute. CCL20 wt Allele. NCI Thesaurus. Code C49735.

Human CCL20 wild-type allele is located within 2q33-q37 and is approximately 4 kb in length. This allele, which encodes C-C motif chemokine 20 protein, is involved in lymphocytes, neutrophils, and dendritic cell chemotaxis and the proliferation of myeloid progenitor cells. 